\title{
IN VITRO HYPOGLYCEMIC AND ANTIMICROBIAL ACTIVITY OF CUCUMIS CALLOSUS (ROTTL.) COGN. FRUIT
}

\author{
SIVA PRASAD PANDA ${ }^{1}$, PALLAB KANTI HALDAR ${ }^{1 *}$, SUDIPTA DAS ${ }^{2}$
}

${ }^{1}$ Department of Pharmaceutical Technology, Jadavpur University, Kolkata - 700 032, West Bengal, India. ${ }^{2}$ Department of Pharmacy, Netaji Subhas Chandra Bose Institute of Pharmacy, Chakadaha - 741 222, West Bengal, India. Email: sivaprasad.panda@gmail.com

Received: 14 March 2016, Revised and Accepted: 22 March 2016

\section{ABSTRACT}

Objective: This research investigated in vitro hypoglycemic and antimicrobial activity of methanolic fruit extract of Cucumis callosus (MECC) (Rottl.) cogn.

Methods: The in vitro antidiabetic ability of MECC was evaluated by inhibition studies of the digestive enzymes including $\alpha$-amylase and $\alpha$-glycosidase. The antimicrobial activity of extract was further evaluated against 21 laboratory strains belongs to 8 bacterial species and 4 fungal species using cupplate agar diffusion assay and agar dilution assay.

Results: Our assay result suggested that the MECC exhibited dose-dependent increase in percentage inhibitory activity on $\alpha$-glycosidase (IC ${ }_{50} 405.37 \mu \mathrm{g} / \mathrm{ml}$ ) and $\alpha$-amylase enzymes (IC $50.55 \mu \mathrm{g} / \mathrm{ml}$ ). The results of antimicrobial activity also showed that the extract inhibited the growth of 13 strains of 7 bacterial species and all fungal species.

Conclusion: The observed inhibitions of $\alpha$-amylase and $\alpha$-glycosidase and inhibition of some microbial species suggested that the MECC may be useful in the management of diabetes mellitus and treatment of some infectious diseases.

Keywords: Cucumis callosus, Diabetes, $\alpha$-amylase, $\alpha$-glycosidase, Antimicrobial.

(C) 2016 The Authors. Published by Innovare Academic Sciences Pvt Ltd. This is an open access article under the CC BY license (http://creativecommons. org/licenses/by/4. 0/) DOI: http://dx.doi.org/10.22159/ajpcr.2016.v9s2.11687

\section{INTRODUCTION}

Diabetes mellitus is a pandemic disease, and the world is facing an escalating epidemic of diabetes. The International Diabetes Federation has estimated that in 2010, 285 million people around the world have diabetes, representing nearly $7 \%$ of the adult world population [1]. Type 2 diabetes mellitus (T2DM) accounts for $90-95 \%$ of all cases of diabetes. Furthermore, T2DM significantly increases the risk of heart disease, stroke, and bacterial and fungal skin infections. T2DM is a disease characterized by a dual defect: (1) By insulin resistance which prevents cells from using insulin properly and (2) degrees of reduced pancreatic insulin secretion [2]. The side effects associated with the prolonged use of insulin and other hypoglycemic drugs have necessitated the demand for safe and effective drugs, especially of herbal origin [3]. Inhibition of $\alpha$-glycosidase (EC 3.2.1.20) and $\alpha$-amylase (EC 3.2.1.1), enzymes involved in the digestion of carbohydrates, can significantly decrease the postprandial increase of blood glucose after a mixed carbohydrate diet, and therefore, can be an important strategy in the management of postprandial blood glucoselevel in Type 2 diabetic patients and borderline patients [4]. $\alpha$-glycosidase and $\alpha$-amylase inhibitors are useful for people taking sulfonylurea medication or metformin, who need an additional medication to keep their blood glucose levels within a safe range. Therefore, the retardation and delay of carbohydrate absorption with a plant-based $\alpha$-glycosidase inhibitor offers a prospective therapeutic approach for the management of T2DM and borderline patients.

Cucumis callous (Rottl.) Cogn. (Cucurbitaceae) commonly called as "Bitter cucumber" in English, "Kachri" in Hindi, is a highly branched very common prostate, perennial herb, distributed throughout India in the arid zones. The fruits are smooth, ovoid, ellipsoid, green variegated stripes and have bitter pulp $[5,6]$. C. callosus is essentially a warm season crop and a long period of warm and humid climate is required [7]. Fruit pulp of $C$. callosus is bitter, acrid, thermogenic, anthelmintic, liver tonic, cardiotonic, appetizer, expectorant, and intellect promoting. Roots are used as emetic and purgative [8]. Traditionally, its fruits and seeds are used for strong memory, remove vertigo, cooling, astringent, bilious disorder, constipation, piles, urticaria, jaundice, amenorrhea, dysmenorrhea, and calculi $[9,10]$. The $C$. callosus fruit is used in the treatment of diabetes mellitus by Srilankan Ayurvedic and traditional physicians [11]. The leaf extract of $C$. callosus topically used in wound healing [4].

The aqueous and alcoholic extract of $C$. callosus (seed) has been reported for its antioxidant activity $[12,13]$. The tribal people of Balasore and Baripada (Odisha, India) use fruits of $C$ callosus during worship, as vegetable and for curing diabetes, epilepsy and diarrhea [14]. Hence, the present study was aimed at evaluating the hypoglycemic and antimicrobial activity of methanolic fruit extract of $C$. callosus (MECC).

\section{METHODS}

\section{Collection of plant}

The fruits of $C$. callosus were collected in the month of July 2014 from village area of Kendrapara and Balasore district, Odisha (India). The plant was authenticated by M. S. Mondal, Botanical Survey of India, Kolkata, India, and a voucher specimen (CNH/1-1(196)/2007/ Tech-II/160) has been preserved in the Pharmacology Research Laboratory, Jadavpur University, Kolkata, for future reference.

\section{Extraction}

The fruits of $C$. callosus were shade dried and then powdered with a mechanical grinder. The powder (500 g) was defatted with petroleum ether at $40^{\circ} \mathrm{C}$ in a Soxhlet extraction apparatus and then extracted similarly with methanol. The solvents were completely removed under reduced pressure to obtain a dry mass. The yields of the petroleum ether and methanol extracts were found to be $2.8 \% \mathrm{w} / \mathrm{w}$ and $9 \% \mathrm{w} / \mathrm{w}$, respectively. The extracts were stored in vacuum desiccators for further use. The preliminary phytochemical screening of the MECC showed the presence of mainly flavonoids, saponin, and terpenoids.

\section{Chemicals}

Pyrocatechol, $\alpha$-amylase, and $\alpha$-glycosidase enzymes were purchased from SRL Pvt. Ltd., Mumbai. Glucose assay kit from Agape Diagnostic 
Pvt. Ltd., Kerala, and Acarbose was obtained from Bicon Pvt. Ltd. All other chemicals used in the study were obtained commercially and were of analytical grade.

\section{Bacterial strains and fungal strains}

Gram-positive strains: Staphylococcus aureus, Bacillus subtilis, and Bacillus pumilus.

Gram-negative strains: Escherichia coli, Vibrio cholerae, Shigella boydi, Klebsiella pneumoniae, Pseudomonas aeruginosa, Salmonella typhimurium, Salmonella choleraesuis, Shigella dysenteriae, and Proteus vulgaris.

Fungal strains: Candida albicans MTCC 183, Aspergillus flavus MTCC 1973, Aspergillus niger MTCC 16404, Cryptococcus albidus MTCC 183.

Microorganisms were obtained from the stock culture of Division of Microbiology, Department of Pharmaceutical Technology, Jadavpur University, Kolkata, India.

\section{In vitro methods employed in antidiabetic studies}

\section{Inhibition of $\alpha$-amylase enzyme}

About $0.05 \mathrm{ml}$ of test samples $(100-1000 \mu \mathrm{g} / \mathrm{ml})$ and $0.05 \mathrm{ml}$ standard drug (100-1000 $\mu \mathrm{g} / \mathrm{ml})$ were separately added to $0.05 \mathrm{ml}$ of $0.1 \mathrm{M}$ phosphate buffer (pH 6.9) containing $0.1 \mathrm{ml}$ of $\alpha$-amylase $(0.5 \mathrm{mg} / \mathrm{ml})$ solution in test tube and were incubated at $25^{\circ} \mathrm{C}$ for 10 minutes. After these, $0.05 \mathrm{ml}$ of $1 \%$ starch solution in $0.1 \mathrm{M}$ phosphate buffer (pH 6.9) was added to each tube. The reaction mixtures were then incubated at $25^{\circ} \mathrm{C}$ for 10 minutes. The reaction was stopped with the addition of $2.0 \mathrm{ml}$ of 3,5 dinitrosalicylic acid color reagent. The test tubes were then incubated in a boiling water bath for 5 minutes, cooled to room temperature. The reaction mixture was then diluted with $10 \mathrm{ml}$ distilled water and absorbance was measured at $540 \mathrm{~nm}$. The generation of maltose was quantified by the reduction of 3, 5 dinitrosalicylic acid to 3-amino-5-nitro salicylic acid. Control represent 100\% enzyme activity and was conducted in a similar way by replacing extract with vehicle [15]

\section{Inhibition of $\alpha$-glycosidase enzyme}

$\alpha$-glycosidase inhibitory activity of the extract was assayed according to Kim et al., with slight modification. The reaction was initiated with the preparation of reaction mixture taking $0.05 \mathrm{ml}$ each of the samples (test and standard) at different concentrations $(100-1000 \mu \mathrm{g} / \mathrm{ml})$ in $0.05 \mathrm{ml}$ of $0.1 \mathrm{M}$ phosphate buffer ( $\mathrm{pH}$ 6.9) followed by incubation at $37^{\circ} \mathrm{C}$ for 15 minutes. After which $0.1 \mathrm{ml}$ of enzyme solution was immediately added to the mixture and incubated at $37^{\circ} \mathrm{C}$ for 15 minutes. Then $0.25 \mathrm{ml}$ of substrate $3 \mathrm{mM} p$-nitro phenyl- $\alpha$-D-glycopyranoside (pNPG) was added to the mixture and again incubated at $37^{\circ} \mathrm{C}$ for 15 minutes, after which the reaction was stopped by the addition of $4 \mathrm{ml}$ of $0.1 \mathrm{mM}$ $\mathrm{Na}_{2} \mathrm{CO}_{3}$. $\alpha$-glycosidase inhibitory activity was determined by measuring the release of p-nitrophenol from pNPG at $405 \mathrm{~nm}$. The control contained all reagents without the tested sample. The reactions were conducted in triplicate. The percentage of inhibition was calculated as:

$\%$ inhibition $=\frac{\Delta \mathrm{Abs}_{\text {control }}-\Delta \mathrm{Abs}_{\text {sample }}}{\Delta \mathrm{Abs}_{\text {control }}} \times 100$

Where

$\mathrm{Abs}_{\text {sample }}$ is the absorbance of sample extract

$\mathrm{Abs}_{\text {control }}$ is the absorbance of the control

The concentration of $\alpha$-glycosidase inhibitor required to inhibit $50 \%$ of $\alpha$-glycosidase activity under the assay conditions is defined as the $\mathrm{IC}_{50}$ value [16].

\section{In vitro methods employed in antimicrobial studies}

Minimum inhibitory concentration (MIC)

The MIC was determined by the agar dilution method in Mueller-Hinton agar medium (Oxoid). Before gelling, $20 \mathrm{ml}$ of agar medium was added to each of the Petri dishes containing a specific concentration of plant extract, or purified compounds, and the Petri dishes were swirled carefully until the agar began to set. Concentrations ranging from 200 to $2000 \mu \mathrm{g} / \mathrm{ml}$ were used for extract. Subsequently, $2 \mu \mathrm{l}$ of bacteria $\left(10^{8}\right.$ colony-forming units $\left.[\mathrm{CFU}] / \mathrm{ml}\right)$ and $2 \mu \mathrm{l}$ fungi $\left(10^{4} \mathrm{CFU} / \mathrm{ml}\right)$ were inoculated using a Steers replicator on the Mueller-Hinton agar surface [17].

\section{Zone of inhibition}

The zone of inhibition was determined by the cup-plate method in Mueller-Hinton agar medium (Oxoid). The antimicrobial activity of MECC was determined using the disk diffusion method. Petri dishes containing $20 \mathrm{ml}$ of Mueller-/Hinton agar medium (Oxoid, Hampshire, England) were seeded with a 24 hrs culture of the microbial strains in Trypticase soy broth (TSB, Oxoid). The inoculum size was adjusted to approximately $10^{8} \mathrm{CFU} / \mathrm{ml}$. The solutions of the plant extract were applied to sterile filter paper disks (Whatman Number 1; $5 \mathrm{~mm}$ in diameter) to give the final concentrations of 2500 and $3000 \mu \mathrm{g} / \mathrm{ml}$ and placed on the surface of the inoculated medium. The plates were incubated at $35^{\circ} \mathrm{C}$ for $24 \mathrm{hrs}$. Antimicrobial activity was determined by measuring the diameter of the inhibited zone formed around the disk [18].

\section{Total phenol estimation}

Total phenolic compound of methanolic fruit extract was determined by Folin-Ciocalteu method. For the preparation of the calibration curve, $1 \mathrm{ml}$ aliquot of $0.025,0.05,0.075,0.1,0.2$, and $0.3 \mathrm{mg} / \mathrm{ml}$ methanolic gallic acid solution was mixed with $5 \mathrm{ml}$ of Folin-Ciocalteu reagent (10 times diluted) and $4 \mathrm{ml}$ sodium carbonate $(75 \mathrm{~g} / \mathrm{L})$. The absorbance at $765 \mathrm{~nm}$ was measured after $1 \mathrm{hr}$ of incubation at $20^{\circ} \mathrm{C}$ in biochemical oxygen demand incubator, and the calibration curve was drawn. To the similar reagent, $1 \mathrm{ml}$ methanolic fruit extract $(4 \mathrm{mg} / \mathrm{ml})$ was mixed as described above and after $1 \mathrm{hr}$ of incubation the absorbance was measured at $765 \mathrm{~nm}$. The total phenol content was expressed in milligrams of gallic acid equivalents (GAE)/g of the extract [19].

\section{The analysis of total flavonoid contents}

The total flavonoid content of extract was determined according to the colorimetric method as described by Moreno et al. To do so, $0.5 \mathrm{ml}$ of each extract was added to test tubes containing $0.1 \mathrm{ml}$ of $10 \% \mathrm{Al}\left(\mathrm{NO}_{3}\right)_{3}$ (w/v), $0.1 \mathrm{ml}$ of $1 \mathrm{M}$ potassium acetate, and $4.3 \mathrm{ml}$ of $80 \%$ ethanol. After incubation for 40 minutes at room temperature, the absorbance was determined at $415 \mathrm{~nm}$. The total flavonoid content was expressed in milligrams of quercetin equivalents $(\mathrm{QE}) / \mathrm{g}$ of the extract [20].

\section{RESULTS}

The methanolic fruit extract was found to contain noticeable amount of total phenol and total flavonoid. The total phenolic content and flavonoid content of MECC were found to be $117.63 \mathrm{mg} \mathrm{GAE} / \mathrm{g}$ of extract

Table 1: $\alpha$-amylase inhibitions by methanol extract of Cucumis callosus

\begin{tabular}{llll}
\hline Sample & $\begin{array}{l}\text { Concentration } \\
(\boldsymbol{\mu g} / \mathbf{m l})\end{array}$ & \% inhibition & $\mathbf{I C}_{\mathbf{5 0}}(\boldsymbol{\mu g} / \mathbf{m l})$ \\
\hline MECC & 100 & $18.66 \pm 0.24$ & 721.55 \\
& 200 & $30.41 \pm 0.14$ & \\
& 400 & $36.33 \pm 0.27$ & \\
& 800 & $53.49 \pm 0.27$ & \\
Acarbose & 1000 & $63.34 \pm 0.11$ & \\
(standard) & & $33.15 \pm 0.69$ & 345.52 \\
& 200 & & \\
& 400 & $48.71 \pm 0.33$ & \\
& 800 & $58.33 \pm 0.14$ & \\
& 1000 & $66.97 \pm 0.39$ & \\
& & $73.38 \pm 0.27$ & \\
\hline
\end{tabular}

All determinations were carried out in triplicate manner and values are expressed as the mean \pm SEM. The $\mathrm{IC}_{50}$ value is defined as the concentration of inhibitor to inhibit $50 \%$ of its activity under the assayed conditions. C. callosus: Cucumis callosus, MECC: Methanolic fruit extract of Cucumis callosus 
and $116.3 \mathrm{mg} \mathrm{QE} / \mathrm{g}$ of extract, respectively, which play a major role in antidiabetic and antimicrobial activity. These quantitative determinations were done using the standard curve of gallic acid and quercetin.

Evaluation of in vitro $\alpha$-amylase inhibitory activity using MECC

There was a dose-dependent increase in percentage inhibitory activity against $\alpha$-amylase enzyme. The extract $100 \mu \mathrm{g} / \mathrm{ml}$ showed a percentage inhibition of $18.66 \pm 0.24$ and $63.34 \pm 0.11$ at $1000 \mu \mathrm{g} / \mathrm{ml}$ (Table 1) The concentration of extract required for $50 \%$ inhibition of $\alpha$-amylase $\left(\mathrm{IC}_{50}\right)$ was found to be $721.55 \mu \mathrm{g} / \mathrm{ml}$, and the $\mathrm{IC}_{50}$ value of standard drug acarbose against $\alpha$-amylase was found to be $345.52 \mu \mathrm{g} / \mathrm{ml}$.

Evaluation of in vitro $\alpha$-glycosidase inhibitory activity of MECC The MECC revealed a significant inhibitory action on $\alpha$-glycosidase enzyme. The percentage inhibition of MECC at $100 \mu \mathrm{g} / \mathrm{ml}$ showed 30.63

Table 2: $\alpha$-glycosidase inhibitions by methanol extract of Cucumis callosus

\begin{tabular}{llll}
\hline Sample & $\begin{array}{l}\text { Concentration } \\
(\boldsymbol{\mu g} / \mathbf{m l})\end{array}$ & \% inhibition & $\mathbf{I C}_{\mathbf{5 0}}(\boldsymbol{\mu g} / \mathbf{m l})$ \\
\hline MECC & 100 & $30.63 \pm 0.30$ & 405.37 \\
& 200 & $39.17 \pm 0.46$ & \\
& 400 & $56.52 \pm 0.23$ & \\
& 800 & $64.38 \pm 0.27$ & \\
Acarbose & 1000 & $86.04 \pm 0.45$ & \\
(standard) & & $40.5 \pm 0.13$ & 236.20 \\
& 200 & $49.12 \pm 0.49$ & \\
& 400 & $63.11 \pm 0.24$ & \\
& 800 & $72.07 \pm 0.56$ & \\
& 1000 & $91.32 \pm 0.18$ & \\
\hline
\end{tabular}

All determinations were carried out in triplicate manner and values are expressed as the mean $\pm \mathrm{SEM}$. The $\mathrm{IC}_{50}$ value is defined as the concentration of inhibitor to inhibit $50 \%$ of its activity under the assayed conditions.

C. callosus: Cucumis callosus, MECC: Methanolic fruit extract of Cucumis callosus \pm 0.30 and $86.04 \pm 0.45$ at $1000 \mu \mathrm{g} / \mathrm{ml}$ (Table 2). The concentration of extract required for $50 \%$ inhibition of $\alpha$-glycosidase $\left(\mathrm{IC}_{50}\right.$ ) was found to be $405.37 \mu \mathrm{g} / \mathrm{ml}$, whereas the $\mathrm{IC}_{50}$ value of standard drug acarbose against $\alpha$-glycosidase was found to be $236.20 \mu \mathrm{g} / \mathrm{ml}$.

\section{Evaluation of in vitro antimicrobial activity of MECC}

The antibacterial and antifungal activities of MECC against 20 laboratory bacterial strains belong to 6 Gram-positive and 14 Gramnegative species and 4 fungal species were tested using agar dilution method as well as by disc diffusion method. The results showed that methanol extract of $C$. callosus has antibacterial activity against three strains of Bacillus species, four strains of $S$. aureus, one strain of Klebsiella pneumoniae 114, Vibrio cholerae 117, S. typhimurium NCTC74, S. dysenteriae 7, E. coli DH5 $\alpha$, and S. boydi (RC). It inhibited the growth of 13 bacterial species and all fungal species at a concentration of $2000 \mu \mathrm{g} / \mathrm{ml}$ and did not show antibacterial activity against the remaining pathogenic bacterial species. The methanol extract of $C$. callosus fruit showed stronger and broader spectrum of antimicrobial activity.

\section{DISCUSSION}

Although there are citations of in vitro antioxidant activity of alcoholic extract and aqueous extract of seeds of $C$. callosus, there are no previous reports on the activity of this extract on in vitro $\alpha$-amylase and $\alpha$-glycosidase activity $[12,13]$. Our in vitro studies demonstrated an appreciable $\alpha$-glycosidase and $\alpha$-amylase inhibitory activity of MECC.

$\alpha$-amylase and $\alpha$-glycosidase are two main enzymes in the human body that are responsible for the breakdown of polysaccharides to more simple sugars. The $\alpha$-amylase hydrolyzes complex polysaccharides to produce oligosaccharides and disaccharides which are then hydrolyzed by $\alpha$-glycosidase to monosaccharides. The monosaccharides are absorbed through the small intestine into the hepatic portal vein and increase postprandial glucose level [21]. Slowing the digestion and absorption of starch by amylase

Table 3: MIC of MECC against various bacterial and fungal species

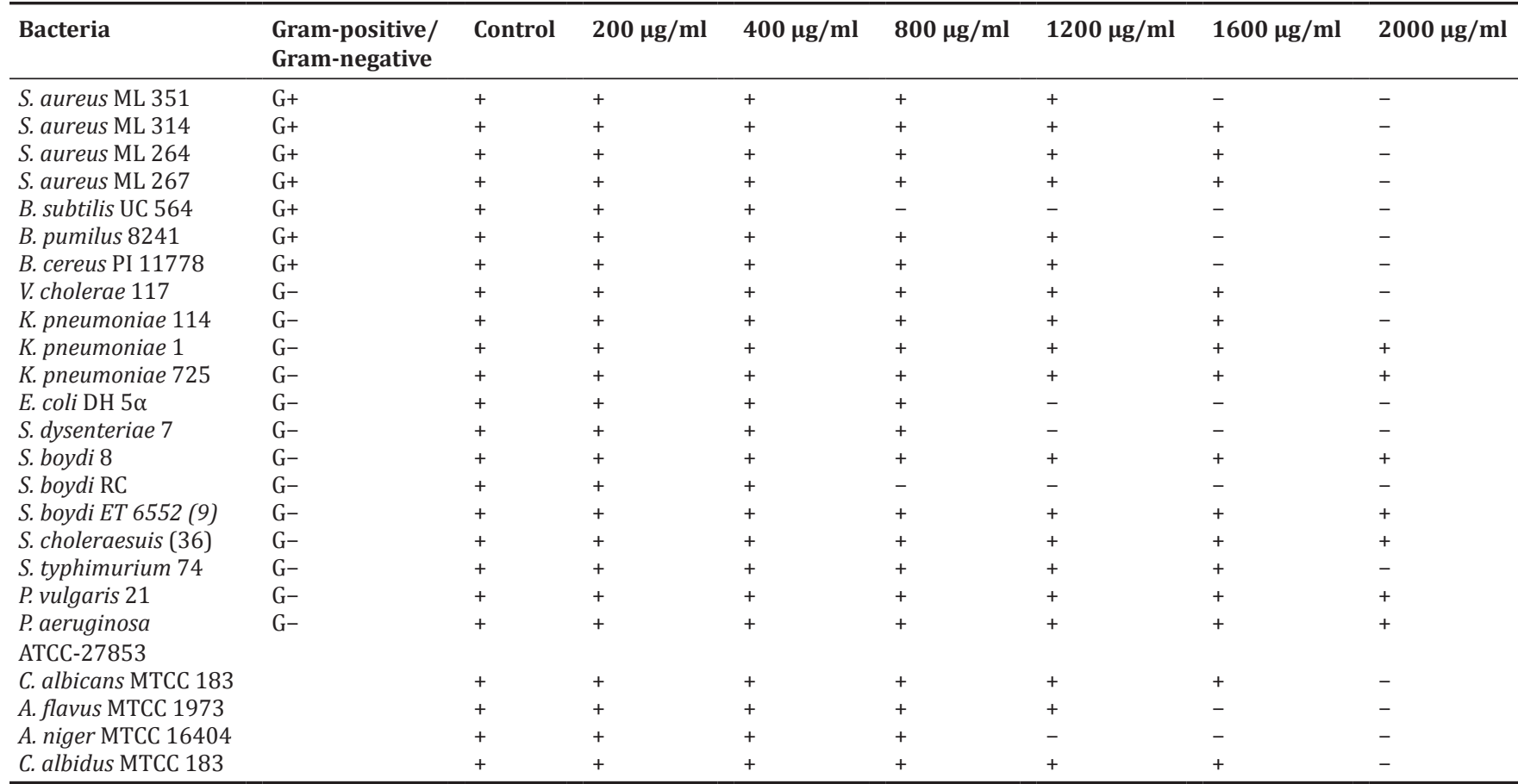

+ : Growth of microorganisms, - : No growth of microorganisms. MIC: Minimum inhibitory concentration, MECC: Methanolic fruit extract of Cucumis callosus, ATCC: American Type Culture Collection, MTCC: Microbial Type Culture Collection. S. aureus: Staphylococcus aureus, B. subtilis: Bacillus subtilis, B. pumilus: Bacillus pumilus, B. cereus: Bacillus cereus, V. cholera: Vibrio cholera, K. pneumoniae: Klebsiella pneumoniae, E. coli: Escherichia coli, S. dysenteriae: Shigella dysenteriae, S. boydi: Shigella boydi, S. choleraesuis: Salmonella choleraesuis, S. typhimurium: Salmonella typhimurium, P. vulgaris: Proteus vulgaris, P. aeruginosa: Pseudomonas aeruginosa, C. albicans: Candida albicans, A. flavus: Aspergillus flavus, A. niger: Aspergillus niger, C. albidus: Cryptococcus albidus 
Table 4: Zone of inhibition of MECC against various bacterial and fungal species

\begin{tabular}{|c|c|c|c|c|c|c|}
\hline Bacteria & $\begin{array}{l}\text { Gram-positive/ } \\
\text { Gram-negative }\end{array}$ & $2500 \mu \mathrm{g} / \mathrm{ml}$ & $3000 \mu \mathrm{g} / \mathrm{ml}$ & $\begin{array}{l}\text { Standard } \\
\text { penicillin }\end{array}$ & $\begin{array}{l}\text { Standard } \\
\text { chloramphenicol }\end{array}$ & $\begin{array}{l}\text { Standard } \\
\text { griseofulvin }\end{array}$ \\
\hline S. aureus ML 351 & $\mathrm{G}+$ & 14 & 15 & 28 & 31 & \\
\hline S. aureus ML 314 & $\mathrm{G}+$ & 13 & 16 & 34 & 38 & \\
\hline S. aureus ML 264 & $\mathrm{G}+$ & 13 & 15 & 21 & 28 & \\
\hline S. aureus ML 267 & $\mathrm{G}+$ & 12 & 12 & 30 & 34 & \\
\hline B. subtilis UC 564 & $\mathrm{G}+$ & 10 & 12 & 18 & 25 & \\
\hline B. pumilus 8241 & $\mathrm{G}+$ & 8 & 11 & 17 & 26 & \\
\hline V. cholerae 117 & G- & 12 & 13 & 24 & 32 & \\
\hline K. pneumoniae 114 & G- & 12 & 14 & 27 & 30 & \\
\hline E. coli DH $5 \alpha$ & G- & 10 & 11 & 34 & 38 & \\
\hline S. dysenteriae 7 & G- & 13 & 15 & 24 & 30 & \\
\hline S. boydi RC & G- & 18 & 20 & 33 & 34 & \\
\hline S. typhimurium 74 & G- & 10 & 12 & 17 & 30 & \\
\hline C. albicans MTCC 183 & & 10 & 16 & & & 34 \\
\hline A. flavus MTCC 1973 & & 15 & 17 & & & 30 \\
\hline C. albidus MTCC 183 & & 17 & 18 & & & 28 \\
\hline
\end{tabular}

Values are zone of inhibition (mm, including the diameter of the bore [6 mm]). Penicillin $(100 \mu \mathrm{g} / \mathrm{ml})$, chloramphenicol $(100 \mu \mathrm{g} / \mathrm{ml})$. Griseofulvin $(100 \mu \mathrm{g} / \mathrm{ml})$.

MECC: Methanolic fruit extract of Cucumis callosus, ATCC: American Type Culture Collection, MTCC: Microbial Type Culture Collection. S. aureus: Staphylococcus aureus, B. subtilis: Bacillus subtilis, B. pumilus: Bacillus pumilus, B. cereus: Bacillus cereus, V. cholera: Vibrio cholera, K. pneumoniae: Klebsiella pneumoniae, E. coli: Escherichia coli, S. dysenteriae: Shigella dysenteriae, S. boydi: Shigella boydi, S. choleraesuis: Salmonella choleraesuis, S. typhimurium: Salmonella typhimurium, P. vulgaris: Proteus vulgaris, P. aeruginosa: Pseudomonas aeruginosa, C. albicans: Candida albicans, A. flavus: Aspergillus flavus, A. niger: Aspergillus niger, C. albidus: Cryptococcus albidus

inhibitors may have the beneficial effects on insulin resistance and glycemic index control in people with diabetes $[22,23]$. Preliminary phytochemical analysis of MECC indicated the presence of phenolic compounds, flavonoids, saponin, and terpenoids. Natural polyphenols have been reported to inhibit the activity of $\alpha$-amylase and $\alpha$-glycosidase [22]. $\alpha$-amylase and $\alpha$-glycosidase inhibitory activity were also related only for oleanane, ursane, and lupeol type terpenoids [24]. The high content of phenolic compounds, saponin, terpenoids, and flavonoids in the extract may also be a contributing factor towards antidiabetic activity. The mechanism by which fruit extract suppressed postprandial hyperglycemia may be due to its action on carbohydrate binding regions of $\alpha$-amylase and $\alpha$-glycosidase enzymes that catalyze hydrolysis of the internal $\alpha-1$, 4 glycosidic linkages in starch and other related polysaccharides. Therefore, this study buttresses the claim that natural inhibitors from dietary plants have $\alpha$-amylase and $\alpha$-glycosidase inhibitory activity and could be used as effective therapy for the management of postprandial hyperglycemia with minimal side effects.

The tested fruit extract was more active against Gram-positive bacteria compared to Gram-negative. In general, Gram-negative bacteria are more resistant than Gram-positive bacteria $[25,26]$. The higher sensitivity of Gram-positive bacteria could be due to the exposure of the outer peptidoglycan layer while Gram-negative bacteria bear an extra outer membrane which includes the asymmetric distribution of the lipids with phospholipids and lipopolysaccharide located in the inner and outer leaflets, respectively, can act as additional barrier which hinders the movement of foreign substance into the cell $[27,28]$ The methanol is a better solvent for more consistent extraction of antimicrobial substances from medicinal plants compared to other solvents, such as water, ethanol, hexane, and chloroform [29,30]. Methanol extract was more active than the aqueous extract against all the human pathogenic organisms [31]. Antibacterial compounds isolated from a large number of plant species throughout the world play a role in plant defense, polyphenolic compounds being known to have multiple functions. Flavonoids, such as naringenin, flavone, and flavonol, including kaempferol, morin, and quercetin and constitute a large group of secondary plant metabolites that have been reported to have antimicrobial activities [32,33]. The high content of phenolic compounds, saponin, and flavonoids in the extract may also be a contributing factor towards antimicrobial activity. This is the first study to provide data that the MECC possess potential antibacterial and antifungal activities.

\section{CONCLUSION}

The results of this study support the folkloric use of this plant in the management of controlling diabetes and post-diabetic bacterial and fungal infections. However, further detailed scientific studies are essential to find out the fundamental mechanisms of antihyperglycemic and antimicrobial activity as well as isolation of active components responsible for this pharmacological property.

\section{ACKNOWLEDGMENTS}

The author Siva Prasad Panda is grateful to AICTE, New Delhi, India, Department of Pharm Tech., Jadavpur University, Kolkata, India, and College of Pharmaceutical Sciences, Puri, for providing financial support to this work.

\section{REFERENCES}

1. Shaw JE, Sicree RA, Zimmet PZ. Global estimates of the prevalence of diabetes for 2010 and 2030. Diabetes Res Clin Pract 2010;87:4-14.

2. Tripathy KD. Insulin, oral hypoglycaemic drugs and glucagon. Essential Medical Pharmacology. $6^{\text {th }}$ ed. New Delhi: Jaypee Brother's Medical Publishers (P) ltd.; 2008. p. 255-74.

3. Bhalodi M, Shukla S, Saluja AK. In vitro antioxidant activity of the flowers of Ipomoea aquatic Forsk. Pharmacogn Mag 2008;4:220-6.

4. Ali H, Houghton PJ, Soumyanath A. Alpha-Amylase inhibitory activity of some Malaysian plants used to treat diabetes; With particular reference to Phyllanthus amarus. J Ethnopharmacol 2006;107:449-55.

5. Rathore M. Nutrient content of important fruit trees from arid zone of Rajasthan. J Hortic Forestry 2009;1(7):103-8.

6. Madhav R. Glimpses of Nature Series (No.4): Our Monsoon Plants Bombay: Bombay Natural History Society; 1959. p. 5.

7. Singh DK. Cucurbits. In: Peter KV, editor. Underutilized and Underexploited Horticulture Crops. Vol. 2. New Delhi: New India Publishing Agency; 2007. p. 175-93.

8. Kirtikar KR, Basu BD. Indian Medicinal Plants. $2^{\text {nd }}$ ed., Vol. 1. Allahabad, India: Lalit Mohan Basu Academy; 1984. p. 1585-8.

9. Rahman AH. Ethno-medicinal investigation on ethnic community in the Northern region of Bangladesh. Am J Life Sci 2013;1(2):77-81

10. Patel PK, Parekh PP, Sorathia KD. Studies on ethnomedicinal aspects of family cucurbitaceae in North Gujarat. UJPBS 2013;1(1):34-6.

11. Ediriweera ER, Ratnasooriya WD. A review on an herb used in treatment of diabetes mellitus by Sri Lankan Ayurvedic and traditional physicians. AYU 2009;30(4):373-91.

12. Chand T, Bhandari A, Bhupendra KK, Sharma A, Pareek A, Bansal VK. In vitro antioxidant activity of aqueous extract of seeds of Cucumis callosus (Rottl.) Cogn. Der Pharm Lett 2012;4(3):840-4.

13. Chand T, Bhandari A, Kumawat BK, Basniwal PK, Sharma S, Verma R. 
In vitro antioxidant activity of alcoholic extract of seeds of Cucumis callosus (Rottl.) Cogn. Am J Pharm Tech Res 2012;2(3):986-92.

14. Gill NS. Review of Cucumis callosus. Glob J Pharm Res 2014;3(2):1901-9.

15. Heidari R, Zareae S, Heidarizadeh M. Extraction, purification, and inhibitory effect of alpha-amylase inhibitor from wheat (Triticum aestivum Var. Zarrin). Pak J Nutr 2005;4(2):101-5.

16. Kim JS, Kwon CS, Son KH. Inhibition of alpha-glucosidase and amylase by luteolin, a flavonoid. Biosci Biotechnol Biochem 2000;64(11):2458-61.

17. NCCLS. Methods for dilution antimicrobial susceptibility tests for bacteria that grow aerobically-Approved standard M7-A5. $5^{\text {th }}$ ed. Villanova, PA: NCCLS; 2000.

18. Mahesh B, Satish S. Antimicrobial activity of some important medicinal plant against plant and human pathogens. World J Agric Sci 2008;4(S):839-43.

19. Ainsworth EA, Gillespie KM. Estimation of total phenolic content and other oxidation substrates in plant tissues using folin-ciocalteu reagent. Nat Protoc 2007;2(4):875-7.

20. Moreno MI, Isla MI, Sampietro AR, Vattuone MA. Comparison of the free radical-scavenging activity of propolis from several regions of Argentina. J Ethnopharmacol 2000;71(1-2):109-14.

21. Ranilla LG, Kwon YI, Apostolidis E, Shetty K. Phenolic compounds, antioxidant activity and in vitro inhibitory potential against key enzymes relevant for hyperglycemia and hypertension of commonly used medicinal plants, herbs and spices in Latin America. Bioresour Technol 2010;101:4676-89.

22. Tundis R, Loizzo MR, Menichini F. Natural products as alphaamylase and alpha-glucosidase inhibitors and their hypoglycaemic potential in the treatment of diabetes: An update. Mini Rev Med Chem 2010;10:315-31.

23. Nair SS, Kavrekar V, Mishra A. In-vitro studies on alpha amylase and alpha glycosidase inhibitory activities of selected plant extracts. Eur J Exp Biol 2013;3(1):128-32.
24. Sales PM, Souza PM, Simeoni LA, Silveira D. A-Amylase inhibitors: A review of raw material and isolated compounds from plant source. J Pharm Pharm Sci 2012;15:141-83.

25. Darah I, Lim CL, Nurul AZ, Nor AS, Shaida FS. Effects of methanol extract of a soft sponge, sp. On bacterial cells: Structural degenerationstudy. Pharm Glob Int J Compr Pharm 2011;2:1-6.

26. Supardy NA, Ibrahim D, Sulaiman SF, Zakaria NA. Inhibition of Klebsiella pneumoniae ATCC 13883 cells by hexane extract of Halimeda discoidea (Decaisne) and the identification of its potential bioactive compounds. J Microbiol Biotechnol 2012;22:872-81.

27. Korir RC, Mutai C, Kiiyukia C, Bii C. Antimicrobial activity and safety of two medicinal plants traditionally used in Bomet district of Kenya. Res J Med Plant 2012;6(5):370-82.

28. Pagès JM, James CE, Winterhalter M. The porin and the permeating antibiotic: A selective diffusion barrier in gram-negative bacteria. Nat Rev Microbiol 2008;6:893-903.

29. Rhouma A, Ben Daoud H, Ghanmi S, Ben Salah H, Romdhane M, Demak M. Antimicrobial activities of leaf extracts of Pistacia and Schinus species against some plant pathogenic fungi and bacteria. J Plant Pathol 2009;91(2):339-45.

30. Dahiya P, Purkayastha S. Phytochemical screening and antimicrobial activity of some medicinal plants against multi-drug resistant bacteria from clinical isolates. Indian J Pharm Sci 2012;74(5):443-50.

31. Pushpahasni K, Sharmila RS, Dhasarathan P. Efficiency of in-vitro antibacterial activity of Syzygium cumini phenolic extract from leaves. Asian J Pharm Clin Res 2015;8(6):211-4.

32. Bidarigh S, Massiha A, Pahlaviani MR, Issazadeh K, Muradov PZ, Azarpour E. Antimicrobial (screening) properties of various plant extracts from Ocimum basilicum L. And Nerium oleander L. Against fungal common rots of potato In vitro bioassay. J Basic Appl Sci Res 2012;2(7):6810-15

33. Al-daihan S, Bhat RS. Antibacterial activities of extracts of leaf, fruit, seed and bark of Phoenix dactylifera. Afr J Biotechnol 2012;11(42):10021-5. 